\title{
Ecogeographic Units and Management Units of Chum Salmon Oncorhynchus keta of the Amur Zoogeographic Province
}

\author{
L. A. Zhivotovsky ${ }^{a, b}$, *, E. V. Podorozhnyuk ${ }^{c}$, S. E. Kulbachnyi ${ }^{c}$, M. V. Shitova ${ }^{a}$, \\ T. A. Rakitskaya ${ }^{a}$, A. I. Nikiforov ${ }^{d}$, G. A. Rubtsova ${ }^{a}$, and K. I. Afanasyev ${ }^{a, b}$ \\ ${ }^{a}$ Vavilov Institute of General Genetics, Russian Academy of Sciences, Moscow, 119333 Russia \\ ${ }^{b}$ Russian Federal Research Institute of Fisheries and Oceanography, Moscow, 107140 Russia \\ ${ }^{c}$ Khabarovsk Branch, Russian Federal Research Institute of Fisheries and Oceanography, Khabarovsk, 680038 Russia \\ ${ }^{d}$ Moscow State Institute of International Relations, Moscow, 119454 Russia \\ *e-mail:levazh@gmail.com
}

Received July 2, 2020; revised August 3, 2020; accepted August 4, 2020

\begin{abstract}
Using the example of chum salmon Oncorhynchus keta in the Amur zoogeographic province, we review the principle of subdividing the species into population groups. On the basis of zoogeographic zoning and biological boundaries of chum salmon groups defined by the spawning areas, taking into account the distribution, migration, and reproduction, as well as estimates of their differentiation using microsatellite DNA markers, we identified eight ecogeographic units in the Amur province. In the Amur zoogeographic region of this province, these included the summer chum salmon of the Amur-Amgun ecoregion and the autumn chum salmon of the Lower Amur (Amur-Amgun and Amur-Ussuri ecoregions); in the Shantar zoogeographic region of the province, the Uda-Tugur and Ulban groups; in the Sakhalin part of the Amur province, groups from the northwestern and northeastern Sakhalin, as well as summer and autumn chum salmon from the Poronai River. These ecogeographic units can be considered as basic spawning management units of chum salmon for this part of the species distribution range.
\end{abstract}

Keywords: chum salmon Oncorhynchus keta, population structure, DNA markers, ecogeographic unit, management unit, aquatic biological resources management, ecology, biogeography, Amur, Shantar region, Sakhalin

DOI: $10.1134 / \mathrm{S} 0032945221040160$

\section{INTRODUCTION}

To develop plans for the management of natural biological resources, namely of their productivity, reproduction, harvesting, and protection, it is necessary to identify management units of the relevant species as population groups living in certain parts of the species distribution range. Let us take an example of chum salmon Oncorhynchus keta Walbaum, which is currently the main object of salmon farming in Russia (Glubokovskii et al., 2010). It is necessary to identify the units of the species, since over the past two decades, the release of farm-produced chum salmon juveniles has more than doubled (Leman et al., 2015); at the same time, unsystematic transfer of chum salmon is not uncommon, including transfer from rivers very distant from the place of release of juveniles. Therefore, it is important to establish restrictions on the transfer of fertilized eggs between fish farms, on the distribution of catch rates, and regulation of reproduction, taking into account the population structure of the species and requirements for reproduction effi- ciency of both farm-produced and wild chum salmon (Zhivotovsky and Smirnov, 2018).

Geographically, chum salmon is the most common species of Pacific salmon, which feeds in the North Pacific Ocean and spawns in rivers of the Asian and American coasts (Salo, 1991; Makoedov et al., 2009). Within the Russian Far East, six to seven main regional spawning groups of chum salmon are distinguished, one of which is represented by the Amur River basin (Karpenko and Rassadnikov, 2004). Amur chum salmon also represents one of the five large genetic clusters of chum salmon from the Far East, identified based on DNA markers (Zhivotovsky et al., 2010). An important special feature of the chum salmon, like other Pacific salmon, is the presence of temporal forms, which were first identified in the Amur chum salmon: summer and autumn (spring and winter races according to: Berg, 1934), which, in the areas inhabited by both, reproduce sympatrically in the same river basins, but on different types of spawning grounds (Birman, 1954; Volobuev et al., 1990; Rosly, 2002; Volobuev and Marchenko, 2011). 
To effectively manage natural resources, management units should be defined in accordance with the biological population and genetic structures of the species. For a given species, there are boundaries determined by its biological characteristics, including the time and place of spawning, the type of spawning grounds, behavior, and migration exchanges. For example, for chum salmon of the mainland coast of Sea of Okhotsk, Volobuev and Marchenko (2011) propose a hierarchical organization of chum salmon: local schools, their temporal forms, and then smaller intra-basin groups. On the contrary, Ivankov et al. (2010) believe that the population structure of chum salmon, like other species of Pacific salmon, is primarily determined by the type of spawning grounds: channel and spring forms; smaller subdivisions are based on the timing and location of spawning.

A combinatory approach for determination of management units as intraspecific population groups would be based on biogeographic principles using data on the ecology and genetics of populations. In particular, the concept of ecogeographic units (EGUs) can be used to determine the management units (Zhivotovsky et al., 2015; Zhivotovsky, 2016a, 2017): each EGU is defined as a group of geographically close populations, the distribution range of which is characterized by similar ecological conditions, with possible exchange of gene flows between them, but significantly separated from other EGUs, which can be tested using DNA markers.

In this study, using the example of chum salmon from the Amur zoogeographic province, we review the principles of subdivision of species and its distribution range on the basis of biogeographic, ecological, and genetic data.

\section{MATERIALS AND METHODS}

The EGU identification procedure consists of two stages (Zhivotovsky et al., 2015; Zhivotovsky, 2016a, 2017). At the first stage, one should preliminarily divide the distribution range of the species into ecologicalgeographical regions, using habitat features important for the studied species, and then subdivide the identified ecological-geographical regions into EGUs, taking into account the biology of the species. Each EGU can include several populations. At the second s t a ge, the selected EGUs should be verified: tested for genetic difference from each other, using multiple sample sets of individuals from the populations of each EGU, after which some EGUs should be combined with each other, and some further subdivided; if there is uncertainty, further research is required.

For example, for freshwater fish and other aquatic organisms that reproduce in rivers and lakes, ecological-geographical regions can be distinguished by superimposing different subdivisions of the species distribution range (based on the river runoff basins, hydrobiological features, ichthyofauna, association of a certain species with a specific habitat, climatic parameters, migrations, etc.). In particular, among the boundaries of spawning EGUs for Pacific salmon and other salmon fishes of the Far Eastern region, for which the critical period of ontogenesis or the entire life takes place in rivers and lakes, can be the biota of freshwater basins, which is also an indicator of the habitat of the studied species. We use the ichthyological zoning according to Chereshnev (1998) as such. The drainage basin can be chosen as another boundary, being an integral unit in the organization of the landscape: it dictates the hydrological regime of the territory, the drainage basins determine the peculiarities of the temperature regime and other characteristics of water bodies (Martynenko and Bocharnikov, 2008; Korytny, 2017). Basin principle of subdivision of the spawning range is essential for chum salmon, as well as for many other species, for which the freshwater period is the most important stage of ontogenesis, since the main adaptive pressure and formation of the homing mechanism occur during this period.

Ecological-geographical regions are further subdivided into EGUs based on the biology of the species: migratory, reproductive, and other characteristics. For chum salmon subdivision, in particular, it is important to take into account the presence of temporal groups, primarily summer and autumn forms, associated with channel and spring spawning grounds (Ivankov et al., 2010; Ivankov and Ivankova, 2013, 2020). Reproductive isolation between races is significant, especially in the Amur River, and is expressed both in morphophysiological differences, in particular in the number of pyloric appendages (Berg, 1934; Grigo, 1953; Kulikova, 1970; Smirnov, 1975; Zhivotovsky et al., 2017), and in genetic markers (Salmenkova et al., 1994; Zhivotovsky et al., 2017).

For DNA testing of EGUs, biological samples of chum salmon were genotyped using microsatellite markers (Ssa197, Ssa20-19, Ogo2, Oke3, Oke11, One103, One 109, Ots3, Oki1-1, and Oki1-2) in accordance with the method of Afanasyev et al. (2011). All studied sample sets of chum salmon are shown in Fig. 1 and are listed in Table 1.

Biological samples were provided: for chum salmon of the Amur River basin, 2018: by E.V. Podorozhnyuk, K.I. Afanasyev, G.A. Rubtsova, M.V. Shitova, and A.I. Nikiforov; for chum salmon of Shantar region (basin of the Tugur and Itkan rivers) and Petrovskaya spit, by S.E. Kulbachnyi; of Tym River, 2012, by A.E. Lapshina; of Langry River, 2008, by A.Yu. Semenchenko and A.A. Yurchenko, and 2011, by Kh.Yu. Kim. For the sake of comprehensive study, we used the published data: on the chum salmon of Tym River in 2003 and 2004 and chum salmon of the Northern Sea of Okhotsk (Afanas'ev et al., 2011), as well as chum salmon of the Amur River basin in 2012 and earlier (Zhivotovsky et al., 2017). 


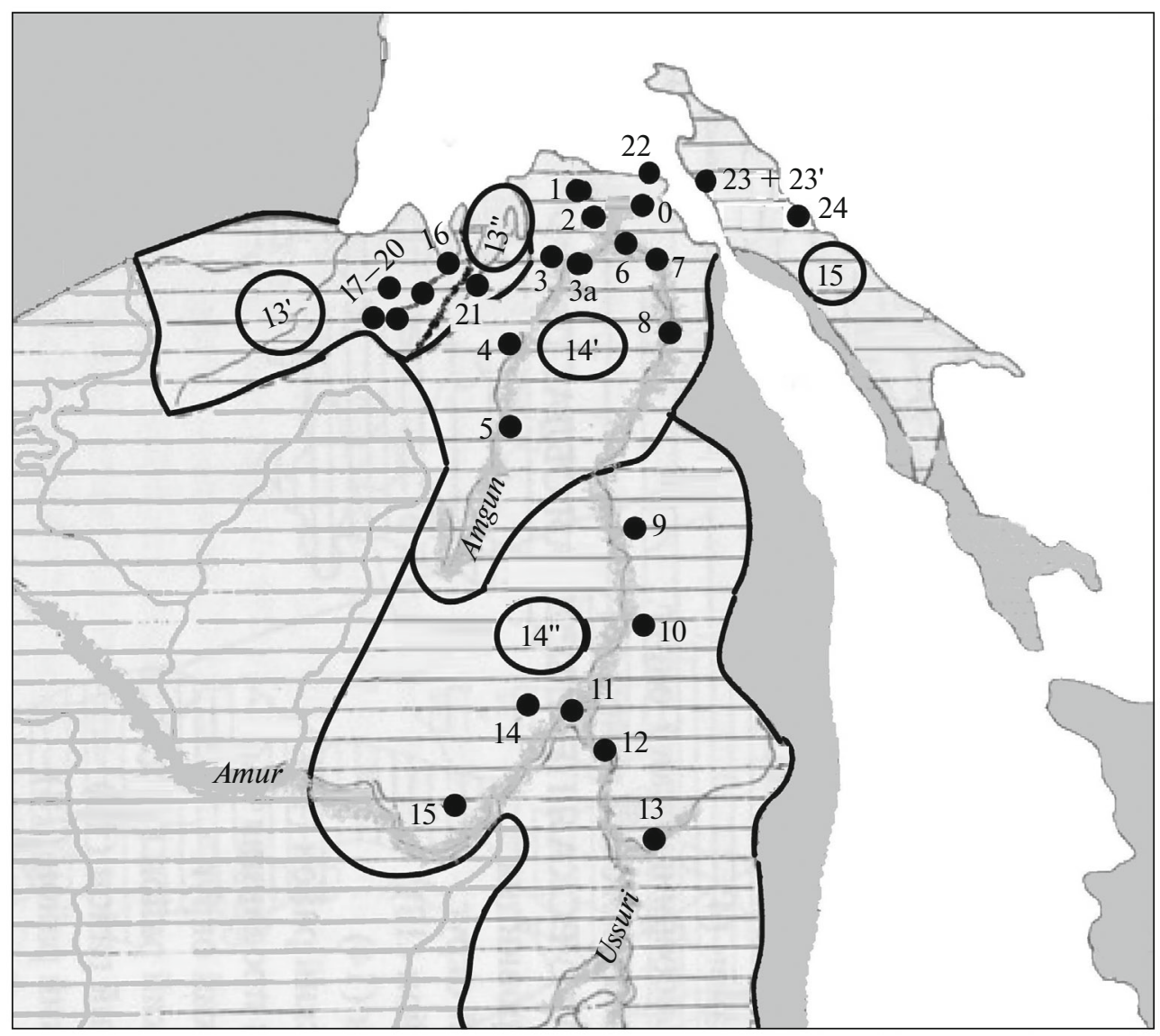

Fig. 1. Amur zoogeographic province (according to: Chereshnev, 1998) (目) and sampling locations of chum salmon Oncorhynchus keta for DNA analysis (๑). Zoogeographic regions (encircled numbers): Shantar (13', Uda-Tugur and 13", Ulban subregions), Amur (14', Amur-Amgun and 14", Amur-Ussuri subregions), and Northern Sakhalin (15). The boundaries of the AmurAmgun and Amur-Ussuri zoogeographic subregions (-) correspond to ecoregions according to: Simonov and Egidarov, 2015. For sample sizes, see Table 1 (mark on the Tym River is mouth).

Population genetic statistics $\left(F_{I S}, \theta_{P}\right.$ and $\theta_{S}$ estimates for $F_{S T}$-statistics of population differentiation, Reynolds' genetic distance, etc.) were calculated following the instructions of Weir (1996) using GDA software (Lewis and Zaykin, 2001). The population samples were clustered using the principal coordinate method in SPSS package for Windows (George and Mallery, 2005). Corrections for multiple comparisons were performed according to the procedure (Benjamini and Hochberg, 1995) in each population sample using 55 tests for Hardy-Weinberg equilibrium and two-locus linkage equilibria. Statistically significant deviation was found for the Oke 3 locus and its disequilibrium with the Oki12 locus in the sample set from Tugur River (autumn form, 2012, $p=0.0028$ after correction). However, there is no scarcity of heterozygotes at this locus $\left(F_{I S}=-0.068\right)$, so the deviation is not associated with the presence of null alleles and could be caused by the small sample size $(n=20)$. In addition, after correction for the entire set of observations (Table 1), the identified deviation manifests itself as insignificant.

\section{RESULTS}

Using the method described above, we select the spawning EGUs of chum salmon of the Amur zoogeographic province according to the following algorithm. First, we divided the part of the species distribution range under study in accordance with the zoogeographic regions of the Far East suggested by Chereshnev (1998), who subdivides the Amur zoogeographic province into the Shantar, Amur, and Northern Sakhalin regions, shown in Fig. 1 under the numbers 13-15 (in accordance with the numeration by the author). We then imposed the biological boundaries of chum salmon groups onto this subdivision of the spawning distribution range and obtained the following EGUs of this species.

In the Amur zoogeographic region, we only study the Amur-Amgun (14') and Amur-Ussuri (14") subregions of the Lower Amur (according to the ecological classification of the Amur river basin (Simonov and Egidarev, 2015)), where the main spawning areas of the Amur chum salmon are located and where our sample sets were collected (Fig. 1); note that the Amur 
Table 1. Collection dates and locations and size of genotyped samples of chum salmon Oncorhynchus keta of Amur zoogeographic province

\begin{tabular}{|c|c|c|c|c|}
\hline № & Collection location & Collection date & Form & $\begin{array}{l}\text { Number of fish } \\
\text { specimen }\end{array}$ \\
\hline 0 & Amur River mouth & July 2003 & Summer & 50 \\
\hline 1 & Lake Orel & July $13-14,2018$ & & 30 \\
\hline 2 & Pal'vinskaya river braid & July 16, 2018 & & 20 \\
\hline \multirow[t]{2}{*}{3} & \multirow[t]{2}{*}{ Somnya River (tributary of Amgun River) } & July $17-21,2018$ & & 14 \\
\hline & & July $26-28,2018$ & & 39 \\
\hline $3 \mathrm{a}$ & $\begin{array}{l}\text { Amgun River (slightly downstream from the } \\
\text { mouth of Somnya River) }\end{array}$ & July 31,2018 & & 100 \\
\hline 4 & Nimelen River (tributary of the Amgun River) & September 13, 2018 & Autumn & 50 \\
\hline \multirow[t]{2}{*}{5} & \multirow[t]{2}{*}{ Duki River (tributary of Amgun River) } & June 2012 & & $48^{*}$ \\
\hline & & September 15, 2018 & & 50 \\
\hline 6 & Khilka River & July 20, 2012 & Summer & 17 \\
\hline \multirow[t]{2}{*}{7} & \multirow[t]{2}{*}{ Gera River } & July 21, 2012 & & 20 \\
\hline & & July $22-24,2018$ & & 53 \\
\hline 8 & Ukhta river braid (Lake Udyl) & July 25,2018 & & 50 \\
\hline 9 & Gur River ("Gursky"SF) & September 21, 2018 & Autumn & 50 \\
\hline \multirow[t]{4}{*}{10} & \multirow[t]{4}{*}{ Anyuy River } & October 2002 & & 46 \\
\hline & & October 4, 2012 & & 19 \\
\hline & & September 19-21, 2018 & & 38 \\
\hline & & September 20, 2018 & & 50 \\
\hline 11 & Pemzenskaya river braid (Amur River) & September 20-October 5, 2012 & & 24 \\
\hline \multirow[t]{3}{*}{12} & \multirow[t]{3}{*}{ Amurskaya river braid (Ussuri River) } & June 2012 & & $48^{*}$ \\
\hline & & September 26-30, 2012 & & 72 \\
\hline & & October 3, 2018 & & 50 \\
\hline 13 & Khor River (tributary of Ussuri River) & October 26,2012 & & 12 \\
\hline \multirow[t]{2}{*}{14} & \multirow[t]{2}{*}{ Tunguska River } & 2003 & & 27 \\
\hline & & September 26-30, 2018 & & 50 \\
\hline 15 & Bidzhan River (Bidzhansky SF) & October 2018 & & 25 \\
\hline \multirow[t]{3}{*}{16} & \multicolumn{4}{|l|}{ Tugur River: } \\
\hline & mouth & August 5, 2009 & Summer & 48 \\
\hline & lower reach & August 18-September 2, 2013 & & 28 \\
\hline \multirow[t]{2}{*}{17} & \multirow[t]{2}{*}{ Tugur River } & September 20, 2008 & Autumn & 34 \\
\hline & & September 2-8, 2012 & & 20 \\
\hline 18 & Tugur River (Gadek river braid) & September 1-5, 2011 & Summer & 25 \\
\hline 19 & Gruntovyi creek (Tugur River) & August 2011 & & 62 \\
\hline \multirow[t]{2}{*}{20} & \multirow[t]{2}{*}{ Konin River (tributary of the Tugur River) } & August 7 and 16-18, 2013 & Autumn & 44 \\
\hline & & September 8-10, 2012 & & 48 \\
\hline 21 & Itkan River & July 9-12, 2009 & & 48 \\
\hline 22 & Petrovskaya spit & July 24, 2009 & & 48 \\
\hline \multirow[t]{3}{*}{23} & \multirow[t]{3}{*}{ Langry River } & July 24, 2008 & & 20 \\
\hline & & August 05, 2008 & & 18 \\
\hline & & October 2011 & & 17 \\
\hline $23^{\prime}$ & Bol'shoi Kamulan (tributary of the Langry River) & October 2011 & & 15 \\
\hline \multirow[t]{3}{*}{24} & \multirow[t]{3}{*}{ Tym River (Ado-Tymovskii SF) } & September 4, 2003 & & 51 \\
\hline & & September 17, 2004 & & 50 \\
\hline & & September 2-24, 2012 & & 27 \\
\hline
\end{tabular}

\footnotetext{
*, juveniles; SF, salmon farm.
} 


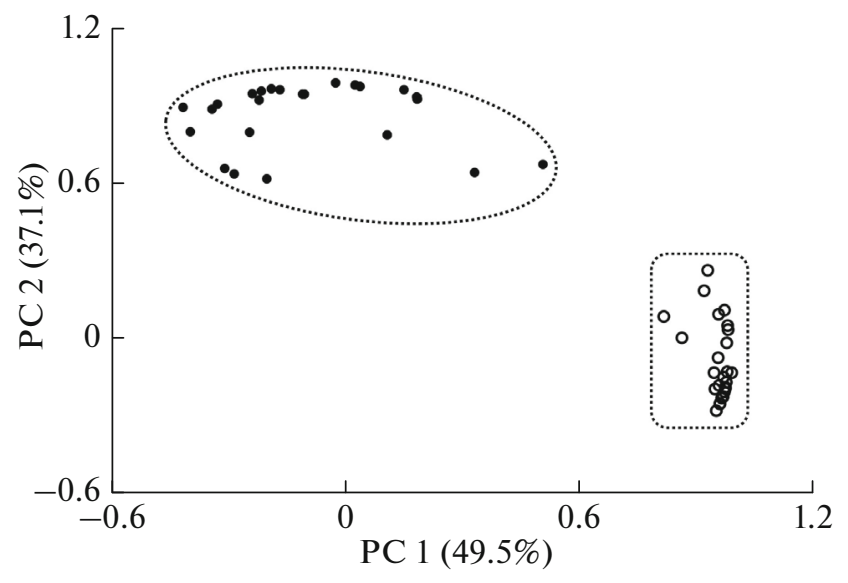

Fig. 2. Genetic differentiation of studied samples of chum salmon Oncorhynchus keta from Amur River basin $(\bigcirc)$ and coast of Sea of Okhotsk ( $\bullet$ in space of principal components (here and in Fig. 3 and 4, PC); genetic cluster of Sea of Okhotsk coast includes samples from Shantar, Northern Sakhalin, and Northern Sea of Okhotsk zoogeographic regions.

chum salmon clearly differs genetically from the chum salmon of the Sea of Okhotsk (Fig. 2). According to the ecological and genetic data, the chum salmon of the Amur zoogeographic region belongs to two EGUs. One of the EGUs is the summer chum salmon, which has a limited spawning range, in contrast to the much more widely spread autumn form. The summer Amur chum salmon was previously identified by Zolotukhin (2019) as a separate EGU, but for certainty we limit its territory to the Amur-Amgun ecoregion (14'), which almost coincides with the established boundaries of spawning area of the summer chum salmon (compare Zolotukhin (2019, Fig. 1) with Simonov and Egidarev (2015. Fig. 2.2)). Genetic data indicate significant differences between the summer form of Amur chum salmon and the autumn form based on the studied DNA markers (Fig. 3), which confirms the earlier conclusion (Zhivotovsky et al., 2017).

As for the autumn form of Amur chum salmon, according to the ecological zoning of the region (Simonov and Egidarev, 2015), the Amur-Amgun ecoregion is an obvious candidate for a separate EGU of the autumn chum salmon. However, genetic data do not allow to divide the studied samples of autumn Amur chum salmon into distinct spatially or temporally separated groups (Fig. 3). Therefore, as the second EGU of the Amur chum salmon, we use the autumn chum salmon, spawning within the entire Lower Amur: Amur-Amgun and Amur-Ussuri ecoregions. (We do not have detailed information about the reproduction of the chum salmon of the Middle and Upper Amur, so we do not analyze it.)

We divide the Shantar zoogeographic region into Uda-Tugur (13') and Ulban (13') ecogeographic units (Fig. 1), since according to Kulbachnyi (2010),

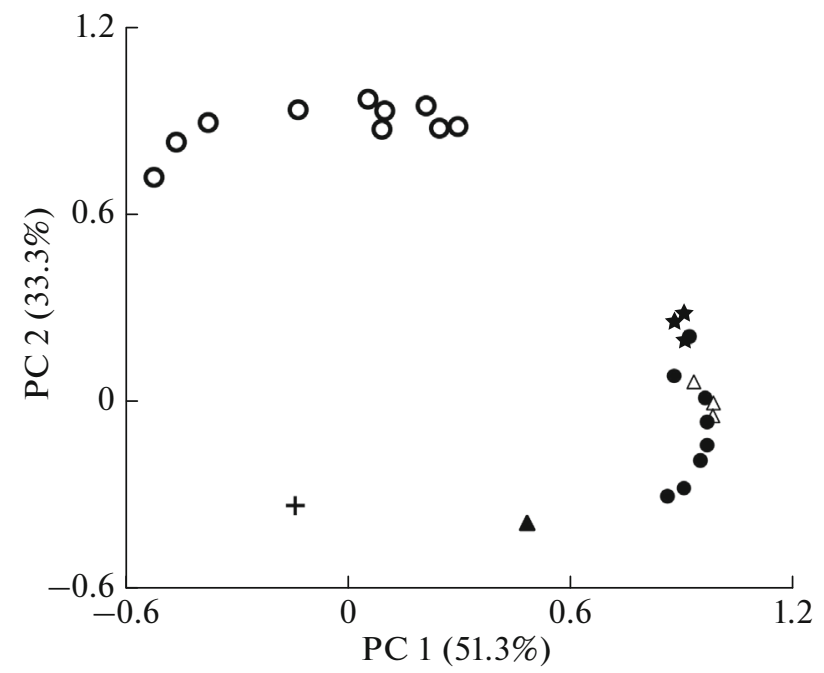

Fig. 3. Genetic differentiation of chum salmon Oncorhynchus keta from Amur of summer $(\bigcirc)$ and autumn forms from Amur-Amgun $(\star)$ and Amur-Ussuri subregions $(\bullet)$, the latter region also includes population samples from Ussuri river basin $((\triangle)$, Amur River braid, and $(\mathbf{\Delta})$, Khor River) and from Pemzenskaya river braid (+).

spawning approaches of chum salmon to the rivers of these subregions occur in opposite directions (from the northeast and southeast, respectively), and therefore possibly belong to different groups of the species. The data in Fig. 4 and Table 2 demonstrate the genetic differences between the Tugur chum slamon and other groups of the species. Preliminary genetic data has verified the Ulban chum salmon as a separate EGU (Table 2); however, further study is required, as the Ulban chum salmon is represented by a single population sample from the Itkan River.

The Northern Sakhalin zoogeographic region includes two EGUs of Sakhalin chum salmon, represented in our material by the Langra and Tym rivers; this region also includes two more previously allocated EGUs: summer and autumn races of chum salmon from the Poronai river basin (Zhivotovsky, 2019).

All EGUs of the Amur zoogeographical province differ significantly from each other based on the DNA markers used in this study (Table 2).

\section{DISCUSSION}

Within the Amur zoogeographic province, we identify four continental EGUs of chum salmon: Amur-Amgun summer EGU, Lower Amur autumn EGU, Uda-Tugur EGU, and, preliminarily, Ulban EGU. Their spawning ranges differ from each other by biogeographic parameters, ecology, and climatic features. Genetically they differ from each other and from other groups of chum salmon of the Far East, including Northern Sakhalin (Figs. 2-4, Table 2). Most notable are the great genetic differences between chum 


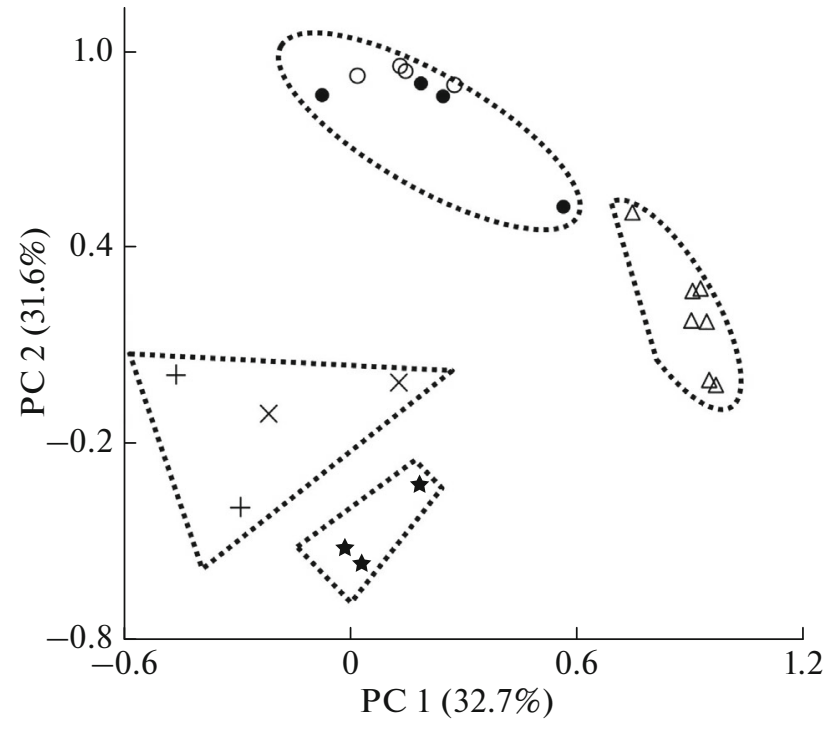

Fig. 4. Genetic differentiation of chum salmon Oncorhynchus keta of Sea of Okhotsk coast: $(\bigcirc)$, creek form, and $(\bullet)$, spring form from the Tugur River; $(\triangle)$, Northern Okhotsk zoogeographic region; $(\star \star \star)$, Tym River; $(\times)$, early, and (+), late forms from Langry River. Groups represented by one population sample are not shown.

salmon from the Amur river basin and chum salmon from the Langry River, despite the geographical proximity of the mouths of these rivers (both of which flow into the Amur estuary), which could hypothetically lead to the exchange of gene flows between them. This assessment may be expanded to include all rivers of the Northwestern Sakhalin, but definitive conclusion would require genetic analysis of chum salmon samples from these rivers.

According to the available zoogeographic, ecologic, and genetic data, the summer chum salmon of the Amur River basin is unambiguously separated into a management unit of the Amur chum salmon. Another management unit is the autumn chum salmon of the Lower Amur (Amur-Amgun and AmurUssuri ecoregions). According to our approach, the Lower Amur autumn chum salmon could be distinguished into not one, but two EGUs: Amur-Amgun (Fig. 1: 14') and Amur-Ussuri (14"), which would be consistent with the conclusion of Zolotukhin (2019). Such distinction is all the more obvious, since the spawning range of the autumn chum salmon of Amur River basin is divided by the type of spawning grounds: in the lower reaches of Amur River, water in most spawning grounds comes from parafluvial springs, while upstream, its spawning grounds are located at discharges of springs (Zolotukhin, 2019). Moreover, the population samples of the autumn chum salmon of Amur-Amgun ecoregion are located on the edge of the genetic cluster of autumn Amur chum salmon (Fig. 3), which could be the additional reason for the preliminary separation of Lower Amur autumn salmon into two EGUs. However, genetically, these two groups of chum salmon do not form different genetic clusters separated from each other, so we combine them into a single EGU. Indeed, the genetic differentiation between them is low and is statistically insignificant $\left(\theta_{S}=0.74, \theta_{P}=0.16, p=0.13\right)$. On the other hand, the statistical insignificance of differences could be due to a small amount of material from the Amur-Amgun ecoregion (only three population samples). Therefore, to test the hypothesis about the subdivision of autumn chum salmon of the Lower Amur into two EGUs, data based on more samples from the Amur-Amgun ecoregion over years would be preferable. In addition, Zolotukhin (2019) has found lake form of chum salmon spawning in Lake Chlya (near Lake Orel); such a rare population also requires genetic testing. We would also note that it is necessary to expand the coverage of Ussuri river basin in the future, as the available three population samples from this location are not representative for such a significant tributary of Amur (Roslyi, 2002; Litvintseva et al., 2009).

For the chum salmon of the southern mainland coast of the Sea of Okhotsk, we limit to the Shantar ecogeographic region (there are no genetic data available for other water bodies), where we define two ecogeographic units: Uda-Tugur and Ulban. Based on the dynamics of population size and ichthyological criteria, Kulbachnyi (2010) identifies two groups of chum salmon in this part of the chum salmon spawning range: Ayan-Tugur (from the Aldoma river to the Uda and Tugur rivers) and Ulban-Iska (from rivers flowing into the Ulbansky bay and further south-east to the rivers of the Sakhalin Bay); i.e., the spawning range of these two groups extends beyond the Shantar zoogeographic region. It is difficult to determine with certainty how these groups correspond to the described ecogeographic units and what is the correspondence between them due to the lack of necessary genetic data. The sample set of chum salmon caught near the Petrovsky spit (Fig. 1) is genetically very different from the chum salmon of Itkan River, so the hereditary unity of the Ulban-Iska school remains questionable. It is possible that it is divided into parts, one of which is the Ulban EGU. On the other hand, the Ulban zoogeographic subregion (Fig. 1) is represented in our material by a single population sample from the Itkan River. Therefore, further genetic study of the chum salmon from this subregion is required for its final verification as a separate EGU.

There is notable tendency to genetic differentiation of the creek and spring forms of chum salmon from the Tugur river basin, corresponding to the summer and autumn forms of Amur chum salmon (Kulbachnyi and Ivankov, 2011). However, the genetic differences between them are immeasurably smaller $\left(\theta_{S}=0.74\right.$, $\left.\theta_{P}=0.21, p=0.06\right)$ than between the seasonal races of Amur chum salmon (Table 2). This is possibly caused to the greater intensity of gene flows between them due 
Table 2. Genetic subdivision of ecogeographic units (EGU) of chum salmon Oncorhynchus keta of Amur zoogeographic province (with Northern Sea of Okhotsk sample sets of chum salmon added for comparison)

\begin{tabular}{l|c|c|c|c|c|c|c}
\hline \multirow{2}{*}{ EGU } & \multicolumn{7}{c}{ EGU } \\
\cline { 2 - 7 } & 1 & 2 & 3 & 4 & 5 & 6 & 7 \\
\hline 1. Amur autumn form & 0.64 & 1.75 & 6.33 & 4.70 & 5.52 & 6.04 & 6.33 \\
\cline { 2 - 7 } 2. Amur summer form & 1.17 & $\frac{0.45^{*}}{p=0.01}$ & 4.05 & 4.02 & 3.85 & 4.91 & 4.58 \\
3. Uda-Tugur & 5.73 & 3.52 & $\frac{0.65}{p=0.01}$ & 2.05 & 2.78 & 3.32 & 1.63 \\
4. Ulban & 4.11 & 3.64 & 1.47 & - & 3.64 & 3.78 & 1.37 \\
5. Northwestern Sakhalin & 4.92 & 3.37 & 2.13 & 3.20 & $\frac{0.72}{p=0.03}$ & 1.44 & 2.57 \\
6. Northeastern Sakhalin & 5.47 & 4.51 & 2.75 & 3.52 & 0.96 & $\frac{0.37}{p=0.06}$ & 2.42 \\
7. Northern Okhotsk & 5.82 & 4.23 & 1.15 & 1.13 & 2.22 & 2.11 & $\frac{0.28}{p=0.08}$ \\
\hline
\end{tabular}

Above diagonal cells, point estimations $\theta_{S}$; below diagonal cells, point estimations- $\theta_{P}$ (lower limits for confidence ranges of $99 \%$ are positive, i.e., $p<0.005$ ); in diagonal cells above horizontal bar, $\theta$ values between populations within EGU; in diagonal cells below horizontal bar, level of significance for difference of $\theta$ from zero. * One sample (Khilka River) deviates strongly from other nine samples of summer Amur chum salmon; with exclusion of this sample, intra-racial inter-population heterogeneity decreases to $0.25 \%(p=0.024)$. Because of this sample, summer chum salmon in previous material (three sample sets in Zhivotovsky et al., 2017) appeared more heterogeneous and had greater differences from autumn Amur chum salmon than in our more extensive material (but due to the same cause, confidence interval of estimations previously had very wide range). “-”, represented by single population sample.

to the spatial proximity of their spawning grounds. Therefore, further more detailed study is required for the chum salmon of other water bodies of the Shantar zoogeographic region, including chum salmon from the Uda and Aldoma rivers.

How do an ecogeographic unit and a management unit relate to each other? A management unit can be understood as a population, school, local school, or other subdivisions of a species (Karpenko, 2013). Ivankov and Ivankova (2020) define a management unit as a local population, which is also a harvest unit. Zhivotovsky (2016b, 2017) defined a management unit as one or several natural and/or artificially bred populations living in similar environmental conditions, possessing similar biological characteristics, genetically close to each other in comparison with their differences from other populations of this species, as well as united by a common management plan (reproduction, fishing, and protection). The latter requirement (unified management plan) means that a management unit is not only a population grouping, but also an economically important subdivision of a species. All other requirements actually relate to an ecogeographic unit.

An ecogeographic unit that unites populations on the basis of common ecological-geographical and genetic characteristics and possible migratory exchanges between them can be a convenient object for defining spawning units of species stock. So, a certain management unit as an economic object can be subdivided into separate local populations, elementary stock units (Ivankov and Ivankova, 2020) or, on the contrary, can be combined with each other into large schools (Karpenko, 2013), if the economic strategy requires it. However, EGU specifically is the basic unit of the species: on the one hand, EGU provides biogeographic and genetic basis for these populations to be grouped into one spawning unit; on the other hand, it determines the boundaries of the management unit, which is useful for practical purposes of developing management strategy for the species. Accordingly, different management units can be controlled and regulated independently of other management units of the given species.

To define management units of anadromous fish species, it is important to take into account their spatial and temporal boundaries (Zhivotovsky, 2019; Ivankov and Ivankova, 2020). Taking into account the population biological, biogeographic, and genetic criteria, ecogeographic unit can be used as the basic spawning unit of chum salmon. Therefore, like EGU, each management unit of chum salmon consists of one or several neighboring natural and/or artificially bred local populations (separate rivers and tributaries of large rivers) that share general conditions and time of reproduction, as well as similar biological features, which are genetically different from other management units of this species. 
Accordingly, we identify four basic chum salmon management units on the investigated part of continental coast of the Amur zoogeographic province: summer chum salmon of the Amur, autumn chum salmon of the Lower Amur, Uda-Tugur, and, preliminarily, Ulban (chum salmon of the Middle and Upper Amur has not been genetically studied, therefore its status in not reviewed in this study). In the Sakhalin part of the Amur province, four management units are also distinguished: the northeastern and northwestern parts of Sakhalin, as well as summer and autumn chum salmon of the Poronai River basin.

\section{ACKNOWLEDGEMENTS}

We thank for their assistance in collection of biological materials of chum salmon of Amur River basin in 2018, researchers of Khabarovsk branch of Russian Federal Research Institute of Fisheries and Oceanography: A.P. Shmigirilov, V.V. Kharitonov, V.Yu. Kolobov, and S.V. Sirotin, as well as inspectors of Amur Territorial Office of Federal Agency for Fishery, I.S. Ikonnikov and S.A. Milintsevich.

\section{FUNDING}

The work was supported by the state assignment topic no. 0112-2019-0002 (subtopic "Ecological and genetic structure of a species") and the agreement between the Vavilov Institute of Genetics, Russian Academy of Sciences, with Khabarovsk branch of Russian Federal Research Institute of Fisheries and Oceanography for R\&D project in 2018-2019. The use of DNA markers for population differentiation was supported by the Russian Science Foundation, project no. 19-16-00101; identification of population groups (including application of statistical methods) was supported by the Russian Foundation for Basic Research, project no. 18-016-00033.

\section{COMPLIANCE WITH ETHICAL STANDARDS}

Conflict of interests. The authors declare that they have no conflicts of interest.

Statement on the welfare of animals. All applicable international, national, and/or institutional guidelines for the care and use of animals were followed.

\section{OPEN ACCESS}

This article is licensed under a Creative Commons Attribution 4.0 International License, which permits use, sharing, adaptation, distribution and reproduction in any medium or format, as long as you give appropriate credit to the original author(s) and the source, provide a link to the Creative Commons license, and indicate if changes were made. The images or other third party material in this article are included in the article's Creative Commons license, unless indicated otherwise in a credit line to the material. If material is not included in the article's Creative Commons license and your intended use is not permitted by statutory regulation or exceeds the permitted use, you will need to obtain permission directly from the copyright holder. To view a copy of this license, visit http://creativecommons.org/licenses/by/4.0/.

\section{REFERENCES}

Afanas'ev, K.I., Rubtsova, G.A., Shitova, M.V., et al., Population structure of chum salmon Oncorhynchus keta in the Russian Far East, as revealed by microsatellite markers, Russ. J. Mar. Biol., 2011, vol. 37, no. 1, pp. 42-51.

Benjamini, Y. and Hochberg, Y., Controlling the false discovery rate: a practical and powerful approach to multiple testing, J. R. Stat. Soc., B, 1995, vol. 57, pp. 289-300. https://doi.org/10.1111/j.2517-6161.1995.tb02031.x

Berg, L.S., Spring and winter races in anadromous fish, $I z v$. Akad. Nauk SSSR, Otd. Mat. Estestv. Nauk, 1934, no. 5, pp. 711-732.

Birman, I.B., Population dynamics and current state of stocks of chum and pink salmons in the Amur River basin, Trudy Soveshchaniya po lososevomu khozyaistvu Dal'nego Vostoka (Proc. Meeting on Salmon Farming in Far East), Moscow: Akad. Nauk SSSR, 1954, pp. 22-37.

Chereshnev, I.A., Biogeografiya presnovodnykh ryb Dal'nego Vostoka Rossii (Biogeography of Freshwater Fishes of Russian Far East), Vladivostok: Dal'nauka, 1998.

George, D. and Mallery, P., SPSS for Windows Step by Step, Boston: Pearson, 2005.

Glubokovskii, M.K., Pavlov, D.S., Leman, V.N., et al., Practical guide on the organization of fishery protected areas by the example of salmon fishes of the Russian Far East, in Lososevye rybokhozyaistvennye zapovednye zony na Dal'nem Vostoke Rossii (Salmon Fishery Protected Zones in the Russian Far East), Moscow: VNIRO, 2010, pp. 98-122. Grigo, L.D., Morphological deviations of summer and autumn chum salmon Oncorhynchus keta (Walbaum), Dokl. Akad. Nauk SSSR, 1953, vol. 92, no. 6, pp. 1225-1228.

Ivankov, V.N. and Ivankova, E.V., Intraspecific reproductive strategies in Pacific salmon of genus Oncorhynchus: fundamental resemblance and species differences, Izv. Tikhookean. Nauchno-Issled. Inst. Rybn. Khoz. Okeanogr., 2013, vol. 173, pp. 103-118.

Ivankov, V.N. and Ivankova, E.V., Ecological and temporal differentiation, stock units, and conservation of population diversity of anadromous fishes, Russ. J. Mar. Biol., 2020, vol. 46 , no. 2 , pp. $68-72$.

https://doi.org/10.1134/S1063074020020054

Ivankov, V.N., Ivankova, E.V., and Kulbachniy, S.E., Intraspecific ecological and temporal differentiation in Pacific salmons: ecological and temporal races and temporal populations of chum salmon Oncorhynchus keta, Izv. Tikhookean. Nauchno-Issled. Inst. Rybn. Khoz. Okeanogr., 2010, vol. 163, pp. 91-105.

Karpenko, V.I., Otsenka sostoyaniya zapasov i upravlenie promyslom tikhookeanskikh lososei na Kamchatke (Assessment of Stock and Monitoring of Fishery of Pacific Salmons in Kamchatka), Petropavlovsk-Kamchatskiy: Kamchat. Gos. Tekh. Univ., 2013.

Karpenko, V.I. and Rassadnikov, O.A., The stock reserves of Far Eastern salmons (Salmonidae) in 1972-2002, Issled. Vodn. Biol. Resur. Kamchat. Sev.-Zap. Chasti Tikhogo Okeana, 2004, no. 7, pp. 14-26. 
Korytny, L.M., The basin concept: from hydrology to nature management, Geogr. Nat. Resour., 2017, vol. 38, no. 2, pp. $111-121$.

https://doi.org/10.1134/S1875372817020019

Kulikova, N.I., Local herds of chum salmon in the Soviet Far East, Extended Abstract of Cand. Sci. (Biol.) Dissertation, Vladivostok: Pac. Sci. Res. Inst. Fish. Oceanogr., 1970.

Kulbachniy, S.E., Ecology and structure of chum salmon populations in the northwestern part of the continental coast of the Sea of Okhotsk, Extended Abstract of Cand. Sci. (Biol.) Dissertation, Vladivostok: Inst. Mar. Biol., Russ. Acad. Sci., 2010.

Kul'bachnyi, S.E. and Ivankov, V.N., Temporal differentiation and conditions of reproduction of chum salmon $\mathrm{On}$ corhynchus keta (Salmoniformes, Salmonidae) from the Tugur River basin (Khabarovsk Krai), J. Ichthyol., 2011, vol. 51, no. 1, pp. 63-72.

Leman, V.N., Smirnov, B.P., and Tochilina, T.G., Pasture salmon breeding in the Far East: current state and existing problems, Tr. VNIRO, 2015, vol. 153, pp. 105-120.

Lewis, P.O. and Zaykin, D., Genetic data analysis: computer program for the analysis of allelic data, Version 1.0, 2001. http://lewis.eeb.uconn.edu/lewishome/software.html.

Litvintseva, V.A., Litvintsev, A.A., and Kotsyuk, E.A., Characteristics of the reserves of fishery reservoirs in Khabarovsk krai: the degree of development, classification, and significance of aquatic objects, Vopr. Rybolov., 2009, vol. 10 , no. 3 (39), pp. 423-432.

Makoedov, A.N., Korotaev, Yu.A., and Antonov, N.P., Aziatskaya keta (Asian Chum Salmon), Petropavlovsk-Kamchatskiy: Kamchat. Nauchno-Issled. Inst. Rybn. Khoz. Okeanogr., 2009.

Martynenko, A.B. and Bocharnikov, V.N., Ecological zonation of the Far East, Izv. Ross. Akad. Nauk, Ser. Geogr., 2008, no. 2, pp. 76-84.

Roslyi, Yu.S., Dinamika populyatsii $i$ vosproizvodstvo tikhookeanskikh lososei v basseine Amura (Population dynamics and Reproduction of Pacific Salmons in the Amur River Basin), Khabarovsk: Khabarovsk. Knizhn. Izd., 2002.

Salmenkova, E.A., Omel'chenko, V.T., Roslyi, Yu.S., et al., Genetic differentiation of chum salmon in the Amur River basin, Genetika, 1994, vol. 30, no. 4, pp. 518-528.

Salo, E.O., Life history of chum salmon (Oncorhynchus keta), in Pacific Salmon Life Histories, Vancouver: Univ. Br. Columbia Press, 1991, pp. 231-309.

Simonov, E.A. and Egidarev, E.G., Characteristic and use of aquatic resources of the Amur River basin, in Kompleksnaya ekologo-ekonomicheskaya otsenka razvitiya gidroenergetiki basseina reki Amur (Complex Ecological-Economic Assessment of Development of Hydropower Energetics in the Amur River Basin), Moscow: WWF, 2015, pp. 21-32.

Smirnov, A.I., Biologiya, razmnozhenie $i$ razvitie tikhookeanskikh lososei (Biology, Reproduction, and Development of Pacific Salmon), Moscow: Mosk. Gos. Univ., 1975.

Volobuev, V.V. and Marchenko, S.L., Tikhookeanskie lososi kontinental'nogo poberezh'ya Okhotskogo morya (biologiya, populyatsionnaya struktura, dinamika chislennosti, promysel) (Pacific Salmons of Continental Coast of the Sea of Ok- hotsk: Biology, Population Structure, Abundance Dynamics, and Fishery), Magadan: Sev.-Vost. Nauchn. Tsentr, Dal'nevost. Otd., Ross. Akad. Nauk, 2011.

Volobuev, V.V., Rogatnykh, A.Yu., and Kuzishchin, K.V., Intraspecies forms of chum salmon Oncorhynchus keta from the continental coast of the Sea of Okhotsk, Vopr. Ikhtiol., 1990, vol. 30, no. 2, pp. 221-228.

Weir, B.S., Genetic Data Analysis II: Methods for Discrete Population Genetic Data, Sunderland, MA: Sinauer, 1996.

Zhivotovsky, L.A., Population structure of species: ecogeographic units and genetic differentiation between populations, Russ. J. Mar. Biol., 2016a, vol. 42, no. 5, pp. 373382.

Zhivotovsky, L.A. Provisional zonation of chum salmon management units in the Russian Far East, in Byulleten' no. 11 izucheniya tikhookeanskikh lososei na Dal'nem Vostoke (Bulletin No. 11 of the Study of Pacific Salmons of the Far East), Vladivostok: TINRO-Tsentr, 2016b, pp. 193-198.

Zhivotovsky, L.A., Two branches, ecological and genetic, in studying the species population structure: history, problems, and solutions, Russ. J. Genet., 2017, vol. 53, no. 11, pp. $1163-1171$.

https://doi.org/10.1134/S1022795417110126

Zhivotovsky, L.A. Ecogeographic units and management units of a species in freshwater ecosystems (by the example of chum salmon off Sakhalin Island), in Printsipy $i$ sposoby sokhraneniya bioraznoobraziya (Principles and Methods of Conservation of Biological Diversity), Yoshkar-Ola: Mariisk. Gos. Univ., 2019, pp. 276-278.

Zhivotovsky, L.A. and Smirnov, B.P., Reproduction strategy of Pacific salmon in Sakhalin oblast, Vopr. Rybolov., 2018, vol. 19, no. 3, pp. 285-299.

Zhivotovsky, L.A., Rubtsova, G.I., Shitova, M.V., et al., Database of microsatellite DNA data on chum salmon of Russian Far East, in Byulleten' no. 5 realizatsii “Kontseptsii dal'nevostochnoi basseinovoi programmy izucheniya tikhookeanskikh lososei" (The Bulletin No. 5 on Implementation "The Concepts of the Far Eastern Basin Program on the Complex Study of Pacific Salmons"), Vladivostok: TINRO-Tsentr, 2010, pp. 53-63.

Zhivotovsky, L.A., Yurchenko, A.A., Nikitin, V.D., et al., Eco-geographic units, population hierarchy, and a two-level conservation strategy with reference to a critically endangered salmonid, Sakhalin taimen Parahucho perryi, Conserv. Genet., 2015, vol. 16, pp. 431-441.

https://doi.org/10.1007/s10592-014-0670-4

Zhivotovsky, L.A., Lapshina, A.E., Mikheev, P.B., et al., Divergence of the seasonal races of chum salmon, Oncorhynchus keta Walbaum, 1792, in the Amur and Poronai rivers: ecology, genetics, and morphology, Russ. J. Mar. Biol., 2017, vol. 43, no. 4, pp. 316-325.

Zolotukhin, S.F., Intraspecific groups of the chum salmon Oncorhynchus keta (Salmonidae) from the Amur River and their distribution within the river basin, Izv. Tikhookean. Nauchno-Issled. Inst. Rybn. Khoz. Okeanogr., 2019, vol. 197, pp. 21-34.

https://doi.org/10.26428/1606-9919-2019-197-21-34

Translated by A. Lisenkova 